\title{
EVALUASI PRODUKSI LARVA BEBERAPA VARIETAS INDUK IKAN NILA UNGGUL
}

\author{
Estu Nugroho \\ Pusat Penelitian dan Pengembangan Perikanan Budidaya \\ Jl. Ragunan 20, Pasar Minggu, Jakarta Selatan 12540 \\ E-mail: engroho@yahoo.com
}

\section{ABSTRAK}

Berbagai varietas induk ikan nila unggul telah dihasilkan oleh anggota Jejaring Pemuliaan Ikan di antaranya adalah Nirwana, BEST, Selfam (Selabintana), dan Central Pertiwi (CP). Kualitas dari benih yang dihasilkan telah menunjukkan tren yang positif dalam pertumbuhan. Peningkatan kualitas ini perlu diimbangi dengan jumlah larva yang dihasilkan sehingga perpaduan antara keduanya dapat menaikkan efisiensi produksi yang merupakan salah satu pilar dalam prinsip "blue economy" yang sekarang sedang dikembangkan oleh Kementerian Kelautan dan Perikanan. Evaluasi dilakukan untuk melengkapi informasi tentang ikan nila unggul yang telah dihasilkan. Pasangan NC (jantan Nirwana $\mathrm{x}$ betina $\mathrm{CP}$ ) dan NN (jantan Nirwana dan betina Nirwana) menghasilkan jumlah larva yang paling banyak yaitu 132 ribu dan 104,467 ekor.

\section{KATA KUNCI : produksi larva, varietas ikan nila unggul}

\section{PENDAHULUAN}

Sejak terbentuknya Jejaring Pemuliaan Ikan pada tahun 2004, Pusat Induk Unggul Nila Nasional yang bertempat di Balai Besar Pengembangan Budidaya Air Tawar Sukabumi telah berhasil memproduksi berbagai varietas unggul ikan nila, baik varietas ikan nila hitam maupun ikan nila merah (Nugroho, 2013). Benih unggul merupakan salah satu pilar yang mendukung industrialisasi perikanan budidaya, seperti yang telah terjadi pada budidaya ikan nila di Cina (Xinhua et al., 2011).

Beberapa varietas ikan nila hitam telah mempunyai daerah distribusi yang sangat luas di antaranya adalah ikan nila Nirwana, BEST, dan Selfam. Selain itu, terdapat pula ikan nila yang dihasilkan oleh pihak swasta yang dihasilkan melalui program pemuliaan yaitu ikan nila Central Pertiwi (CP).

Produksi budidaya ikan nila di KJA (Kantong Jaring Apung) dapat ditingkatkan dengan menggunakan benih unggul ikan nila hasil pemuliaan seperti yang didapatkan oleh Nugroho (2012). Tercatat peningkatan laba dan produksi yang cukup nyata dibandingkan dengan budidaya ikan nila di KJA dengan menggunakan varietas ikan nila lokal yang banyak digunakan oleh masyarakat pada saat ini.

Peningkatan kualitas benih ikan nila unggul ini perlu diikuti dengan peningkatan kuantitas larva yang dihasilkan oleh induk-induk yang digunakan. Dengan demikian maka akan semakin meningkat pula efisiensi dalam produksi budidaya ikan nila secara keseluruhan. Peningkatan efisiensi merupakan salah satu prinsip yang diterapkan dalam konsep "blue economy" yang saat ini menjadi acuan program dari Kementerian Kelautan dan Perikanan. Evaluasi terhadap produksi larva dari varietas unggul ikan nila dilakukan dengan membandingkan secara langsung jumlah larva yang diproduksi selama 3 bulan pemijahan di kolam tembok.

\section{Varietas Ikan Nila dan Pemeliharaannya}

Beberapa varietas ikan nila unggul telah diuji kemampuannya dalam menghasilkan larva atau benih untuk kegiatan budidaya, di antaranya adalah ikan nila Nirwana, BEST, Selfam, dan ikan nila CP, serta ikan nila varietas lokal sebagai salah satu kontrolnya.

Varietas ikan nila Nirwana dikoleksi dari Balai Benih Ikan Sentral Wanayasa. Varietas ikan nila BEST didatangkan dari Balai Penelitian dan Pengembangan Budidaya Air Tawar Bogor. Ikan nila Selfam berasal dari Balai Besar Pengembangan Budidaya Air Tawar Sukabumi dan ikan nila CP didapatkan dari PT Charoen Pophand, Pabuaran, 
Tabel 1. Bobot induk betina, jumlah induk betina, dan proporsi jantan:betina

\begin{tabular}{lcccccc}
\hline & CC = 1 & NN = 2 & NC = 3 & NB = 4 & NS = 5 & LL = 6 \\
\hline Rataan bibit induk betina (g) & 600 & 350 & 639 & 416 & 399 & 200 \\
Jumlah induk betina/kolam & 340 & 350 & 330 & 250 & 313 & 250 \\
Proporsi jantan : betina/kolam & $1: 1,6$ & $1: 5,3$ & $1: 5,5$ & $1: 4,2$ & $1: 5,2$ & $1: 5,0$ \\
\hline
\end{tabular}

Keterangan: CC = CP x CP; NN = Nirwana x Nirwana; NC = Nirwana x CP; NB = Nirwana x BEST; NS = Nirwana x Selfaml; LL = Lokal x Lokal

Sukamandi. Semua koleksi dikumpulkan dalam kurun waktu 2008-2010.

Induk-induk dari varietas terpilih, dipelihara, dan dipijahkan secara terpisah dalam kolam tembok dengan ukuran $25 \mathrm{~m}$ x $4 \mathrm{~m}$. Jumlah dan bobot rata-rata induk betina, serta proporsi antara induk jantan dan betina tercantum pada Tabel 1. Induk diberi pakan berupa pelet apung dengan kadar protein $32 \%$ sebanyak $2 \%-3 \%$ per hari dengan frekuensi pemberian pakan 3x dalam satu hari. Waktu pemijahan dilakukan dengan menggabungkan secara massal antara induk jantan dan betina setelah dimatangkan gonadnya selama 14 hari. Selama pemeliharaan 30 hari, larva mulai dikumpulkan sejak hari ke-14 dilakuakn setiap hari dan pada hari ketiga puluh larva dipanen secara total. Tahapan ini dilakukan selama 3 bulan sebelum induk-induk ikan diistirahatkan dan dimatangkan gonadnya kembali dengan memelihara secara terpisah antara induk jantan dan betina.

\section{Produktivitas}

Secara rata-rata, jumlah larva yang dihasilkan selama waktu pemeliharaan 3 bulan menunjukkan bahwa varietas ikan nila NC (jantan Nirwana $\mathrm{x}$ betina $\mathrm{CP}$ ) menghasilkan jumlah larva yang terbanyak yaitu 132 ribu ekor diikuti secara berturut-turut oleh ikan nila NN (jantan Nirwana x betina Nirwana; 104 ribu), ikan nila NS (jantan Nirwana $x$ betina Selfam; 103 ribu), ikan nila NB (jantan Nirwana $\mathrm{x}$ betina BEST; 69 ribu), ikan nila CC (jantan $\mathrm{CP} x$ betina $\mathrm{CP}$; 57 ribu) dan ikan nila LL (jantan Lokal $\mathrm{x}$ betina Lokal; 45 ribu) (Tabel 2).

Ikan nila $\mathrm{CP}$ dan NN diduga mempunyai kekerabatan yang lebih dekat dibandingkan dengan varietas ikan nila lainnya. Hal ini terlihat dari nilai $\mathrm{CV}$, hibrida antara keduanya mempunyai nilai $\mathrm{CV}$ yang relatif lebih rendah dibandingkan dengan salah satu galur murninya yaitu NN. Jika mempunyai kekerabatan yang tidak terlalu dekat maka kemungkinan hibrida antara varietas-varietas yang diuji akan mempunyai nilai keragaman yang lebih tinggi dari salah satu galur murninya misalnya hibrida NB dan NS dibandingkan ikan nila NN. Keragaman NS mendekati dengan keragaman yang dimilki oleh ikan nila varietas lokal (LL). Program seleksi untuk parameter jumlah larva yang dihasilkan akan lebih besar peluang keberhasillanya jika dilakukan pada pasangan NS dan LL dibandingkan pada pasangan lainnya.

Tabel 2. Jumlah total produksi larva (ekor)/bulan

\begin{tabular}{ccccccc}
\hline \multirow{2}{*}{ Bulan } & \multicolumn{7}{c}{ Strain } \\
\cline { 2 - 7 } & $\mathrm{CC}=\mathbf{1}$ & $\mathrm{NN}=\mathbf{2}$ & $\mathrm{NC}=\mathbf{3}$ & $\mathrm{NB}=\mathbf{4}$ & $\mathrm{NS}=\mathbf{5}$ & $\mathrm{LL}=\mathbf{6}$ \\
\hline 1 & 48.800 & 56.600 & 87.800 & 43.000 & 36.800 & 73.400 \\
2 & 51.200 & 132.200 & 158.600 & 102.800 & 129.400 & 24.000 \\
3 & 72.600 & 124.600 & 149.600 & 61.200 & 143.800 & 39.800 \\
Rataan & 57.200 & 104.467 & 132.000 & 69.000 & 103.333 & 45.733 \\
SD & 12.528 & 41.628 & 38.654 & 30.654 & 58.068 & 25.229 \\
CV & 21,90 & 39,85 & 29,20 & 44,43 & 56,19 & 55,17 \\
\hline
\end{tabular}

Keterangan: CC = CP x CP; NN = Nirwana $x$ Nirwana; NC = Nirwana $x$ CP; NB = Nirwana x BEST; NS = Nirwana $x$ Selfaml; LL = Lokal $x$ Lokal 
Lebih jauh, jika diasumsikan induk ikan nila rata-rata mempunyai jumlah larva sekitar 1.000 ekor, maka besarnya jumlah induk betina yang memijah dapat diestimasi seperti tercantum pada Tabel 3. Rata-rata jumlah induk betina tertinggi yang memijah setiap bulannya adalah ada pada pasangan NC (40\%), diikuti oleh pasangan NS $(33,01 \%)$; NN $(29,85 \%) ;$ NB $(27,60 \%) ;$ LL $(18,29 \%)$; dan CC $(16,82 \%)$.

Selanjutnya jumlah produksi larva dari masingmasing pasangan dibandingkan dengan jumlah larva yang diproduksi oleh galur murni NN dan CC maka diketahui bahwa hanya pasangan NC yang lebih memproduksi larva dari NN, sebaliknya hanya pasanagn LL yang berada pada produktivitas larva dari pasangan CP. Sedangkan pasangan lainnya mempunyai jumlah larva yang lebih tinggi dibandingkan CP (Tabel 4).

\section{KESIMPULAN}

Pasangan NC (jantan Nirwana $\mathrm{x}$ betina $\mathrm{CP}$ ) dan NN (jantan Nirwana dan betina Nirwana) menghasilkan jumlah larva yang paling banyak yaitu 132.000 dan 104.467 ekor.

\section{REKOMENDASI}

Budidaya ikan nila di KJA hendaknya menggunakan benih sebar yang dihasilkan oleh pasangan induk jantan varietas Nirwana dan induk betina varietas $C P$.

Tabel 3. Estimasi jumlah induk betina yang memproduksi larva (ekor)

\begin{tabular}{ccccccc}
\hline \multirow{2}{*}{ Bulan } & \multicolumn{7}{c}{ Strain } \\
\cline { 2 - 7 } & $\mathrm{CC}=\mathbf{N N}=\mathbf{2}$ & $\mathrm{NC}=\mathbf{3}$ & $\mathrm{NB}=4$ & $\mathrm{NS}=\mathbf{5}$ & $\mathbf{L L}=\mathbf{6}$ \\
\hline \multirow{2}{*}{1} & 49 & 57 & 88 & 43 & 37 & 73 \\
& $(14,35 \%)$ & $(16,17 \%)$ & $(26,61 \%)$ & $(17,20 \%)$ & $(11,76 \%)$ & $(29,36 \%)$ \\
2 & 51 & 132 & 159 & 103 & 129 & 24 \\
& $(15,06 \%)$ & $(37,77 \%)$ & $(48,06 \%)$ & $(41,12 \%)$ & $(41,34 \%)$ & $(9,06 \%)$ \\
3 & 72 & 125 & 150 & 61 & 144 & 40 \\
& $(21,06 \%)$ & $(35,60 \%)$ & $(45,33 \%)$ & $(24,48 \%)$ & $(45,94 \%)$ & $(15,92 \%)$ \\
Rataan & 57 & 104 & 132 & 69 & 103 & 46 \\
SD & $(16,82 \%)$ & $(29,85 \%)$ & $(40,00 \%)$ & $(27,60 \%)$ & $(33,01 \%)$ & $(18,29 \%)$ \\
CV & 12.528 & 41.628 & 38.654 & 30.654 & 58.068 & 25.229 \\
\hline
\end{tabular}

Asumsi: produktivitas $=1.000$ ekor/induk

Tabel 4. Variasi produksi larva terhadap galur nirwana dan $\mathrm{CP}$

\begin{tabular}{lcc}
\hline & Nirwana & CP \\
\hline Nirwana x CP & 1,2635609 & 2,3076923 \\
Nirwana x BEST & 0,6604978 & 1,2062937 \\
Nirwana x Selfam & 0,9891512 & 1,8065268 \\
Lokal x Lokal & 0,4377792 & 0,7995338 \\
\hline
\end{tabular}

\section{DAFTAR ACUAN}

Nugroho, E. 2012. Budidaya nila unggul dongkrak keuntungan. TROBOS edisi 150, tahun XIII, Maret.

Nugroho, E. 2013. Nila unggul \# 1. Penebar Swadaya. Jakarta, $116 \mathrm{hlm}$.

Xinhua, Y., Pao, X., Zaijie, D., Wei, Y., \& Xiaojun, J. 2011. Training course on tilapia seed production for Indonesia SAFVER Project. Freshwater Fisheries Research Center, Wuxi, China. 120 pp. 
